\title{
Screening of Karanj, Pongamia pinnata L. against various insect pests under agro-silvi pattern of cropping system at Raipur (C.G.)
}

\author{
- CHANDRAMANI SAHU*, J. L. GANGULI, A. KERKETTA AND K.L. PAINKRA
}

Department of Entomology, College of Agriculture, Indira Gandhi Agricultural University, RAIPUR (C.G.) INDIA

\section{ARITCLE INFO}

Received : 23.07 .2016

Revised : 09.09.2016

Accepted : 23.09 .2016

\section{KEY WORDS :}

Karanj, Provenances, Population, Screening

*Corresponding author:

Email : chandrasahu2111@gmail.com

\begin{abstract}
Six provenances of $P$. pinnata were screened namely Raipur, Ambikapur, Jabalpur, Nainpur, Zaheerabad and Keesaragutta. Fortnightly recorded of various insect pests along with the number of their associated natural enemies were also recorded. The major insect pests were the common banded awl, leaf webber, leaf blotch miner, pod borer, leaf hopper, leaf eating beetle, mealy bugss and green lace wing, mantis along with some species of spiders were observed as the natural enemies. Maximum population of common banded awl, Hasora chromus was recorded as 17.00 larvae/twig on provenance Jabalpur. Maximum infestation (36.3\%) seeds were by pod borer, Ephestia sp. was recorded on Nainpur. Population of leaf webber was maximum (3.92 larvae/ twig) on Jabalpur and Keesaragutta, blotch miner (8.41 blotches/leaf) on Jabalpur, leaf eating beetles (5.25 beetles/twig) Zaheerabad, leaf hoppers 5.58 (nymphs and adults/ leaf) on Keesaragutta, mealy bugss (6.50 nymphs and adults/twig).
\end{abstract}

How to view point the article : Sahu, Chandramani, Ganguli, J.L., Kerketta, A. and Painkra, K.L. (2016). Screening of Karanj, Pongamia pinnata L. against various insect pests under agrosilvi pattern of cropping system at Raipur (C.G.). Internat. J. Plant Protec., 9(2) : 570-577, DOI : 10.15740/HAS/IJPP/9.2/570-577. 